\title{
PENDAMPINGAN MANAJEMEN PEMBELAJARAN DARING DITENGAH PANDEMI COVID 19 BAGI GURU MADRASAH IBTIDAIYAH
}

\author{
Nafiah $^{1)}$, Syamsul Ghufron²), Sri Hartatik¹) \\ 1)Prodi PGSD, Fakultas Keguruan dan IImu Pendidikan, Universitas Nahdlatul Ulama Surabaya, Surabaya, \\ Jawa Timur, Indonesia \\ 1, 2)Prodi Pendidikan Profesi Guru, Fakultas Keguruan dan Ilmu Pendidikan, Universitas Nahdlatul Ulama Surabaya, \\ Surabaya, Jawa Timur, Indonesia \\ Jawa Timur, Indonesia \\ Corresponding author : Nafiah \\ E-mail :nefi_23@unusa.ac.id
}

Diterima 13 Maret 2021, Direvisi 15 April 2021, Disetujui 16 April 2021

\begin{abstract}
ABSTRAK
Tujuan pengabdian masyarakat ini adalah untuk memberikan pelatihan dan pendampingan manajemen pembelajaran daring bagi guru di tengah pandemi covid 19 di MI Tarbiyatul Islamiyah Bojonegoro. Metode pelaksanaan dalam program pengabdian kepada masyarakat melalui pelatihan dan pendampingan ini melalui tiga kegiatan: pra kegiatan, pelaksanaan kegiatan, dan pasca kegiatan. Hasil dari kegiatan masyarakat ini adalah berupa jasa berupa pelatihan dan pendampingan dan artikel pengabdian masyarakat yang dipulikasikan. Hasil pengabdian masyarakat yang dilakukan menunjukkan bahwa kegiatan pelatihan dan pendampingan manajemen pembelajaran berbasis daring bagi guru di tengah pandemi covid 19 di MI Tarbiyatul Islamiyah Bojonegoro berjalan dengan sukses karena dukungan dari berbagai pihak yang terlibat dengan pengabdian mansyaraat. Guru sangat antusias dalam kegiatan pelatihan dan pendampingan secara daring, guru juga sudah memahami caramerencanakan, melaksanakan dan mengevaluasi siswa secara daring. Rencana tindak lanjut pelaksanaan pengabdian masyarakat sebagai saran adalah mengadakan pelatihan dan pendampingan dalam melaksanakan pembelajaran daring dengan menggunakan aplikasi digital bagi guru sekolah dasar.
\end{abstract}

Kata kunci: manajemen; pembelajaran; daring; covid 19

\begin{abstract}
The purpose of this community service is to give training and mentoring online learning management for teachers in the midst of the Covid 19 pandemic at MI Tarbiyatul Islamiyah Bojonegoro. The method of this community service program through training and mentoring is through three activities are: Preactivity, implementation of activities, and post-activity. The result of this community activity is in the form of services in the form of training and mentoring, published articles of community service. The results of the community service carried out show that online-based learning management training and assistance activities for teachers in the midst of the COVID-19 pandemic at MI Tarbiyatul Islamiyah Bojonegoro are running successfully because of the support of various parties involved with community service. The teacher is very enthusiastic about online training and mentoring activities, the teacher also understands how to plan, implement and evaluate students online. The follow-up plan for implementing community service as a suggestion is to hold training and assistance in implementing online learning using digital applications for elementary school teachers.
\end{abstract}

Keywords: learning; management; online; covid 19

\section{PENDAHULUAN}

Pada saat ini adanya wabah virus covid 19 yang ada Indonesia memberikan dampak pada dunia Pendidikan, salah satunya pelaksanaan pembelajaran yang dilakukan secara daring. Permasalahan yang terjadi pada guru-guru MI Tarbiyatul Islamiyah, Bojonegoro adalah bagaimana memanajemen pembelajaran daring yang menyenangkan bagi siswa. Suatu pembelajaran akan berjalan secara efektif apabila dilakukan dengan perencanaan, pelaksanaan dan evaluasi yang baik atau dengan kata lain melakukan manajemen pembelajaran dengan baik. Pembelajaran daring merupakan suatu pembelajaran yang dilakukan dengan menggunakan jaringan internet. Manajemen pembelajaran merupakan kemampuan dalam mengelola secara operasional dan efesien 
terhadap komponen-komponen yang berkitan dengan pembelajaran, sehingga menghasilkan nilai tambah terhadap komponen tersebut menurut norma/standar yang berlaku.

Penerapan sistem manajemen pembelajaran (Learning Management System) akan menjadi efektif dengan memperhatikan kondisi guru yang menggunakan sistem untuk melakukan pembelajaran "an effective implementation of LMS should highly consider academics who will use such systems for teaching"(Alharbi and Drew, 2014) Sistem manajemen pembelajaran (LMS) merupakan suatu sistem manajemen pembelajaran dapat digunakan dalam proses pembelajaran oleh guru, tapi masih banyak guru yang belum menguasainya. Learning management system (LMS) berupa software atau aplikasi yang menggunakan jaringan internet dalam pelaksanaannya. Banyak sekali LMS yang dapat digunakan guru secara gratis seperti google classroom, moodle dan lain sebagainya. Dengan memanfaatkan LMS maka guru akan dapat merencanakan, melaksanakan dan mengevaluasi kegiatan pembelajaran yang dilakukan secara daring.

Permasalahan yang terjadi pada guru sekolah dasar adalah rendahnya penguasaan manajemen pembelajaran daring guru ditengah pandemi covid 19. Manajemen pembelajaran daring meliputi perencanaan pembelajaran daring, pelaksanaan pembelajaran daring dan evaluasi pembelajaran daring. Pelaksanaan manajemen pembelajaran daring dapat dilakukan dengan menggunakan sistem manjemen pembelajaran. Sistem manajemen pembelajaran alat yang sangat penting untuk mengembangkan desan kurikulum, manajemen pembelajaran siswa dan motivasi siswa untuk belajar(Nafiah and Hartatik, 2020). Ada banyak sistem manjemen pembelajaran yang bisa dilakukan guru untuk melakukan pembelajaran secara daring ditengah pandemi covid 19.

Berdasarkan hasil penelitian yang dilakukan Nafiah dan Hartatik (2020) yang berjudul survey di MI Tarbiyatul Islamiyah Bojonegoro, kemampuan guru dalam manajemen pembelajaran daring bagi guru ditengah pandemi covid 19 ditemukan kemampuan guru dalam memanajemen pembelajaran daring ditengah pandemi covid 19 masih rendah. Kendala yang dihadapi guru adalah karena 1) guru masih belum menguasi perencanaan pembelajaran daring, 2) guru cenderung menggunakan whatsapp dalam melakukan pembelajaran daring dan lebih banyak memberikan tugas pada siswa, karena kurangnya pengetahuan guru tentang aplikasi pembelajaran daring, 3) pengetahuan guru tentang evaluasi pembelajaran daring masih rendah. Pelatihan dan pendampingan manajemen pembelajaran daring dilakukan pada Guru MI Tarbiyatul Islamiyah. Berdasarkan analisis situasi terhadap permasalahan mitra, maka untuk mengatasi permasalahan mitra tentang rendahnya kemampuan guru dalam melakukan manajemen pembelajaran daring ditengah pandemi covid 19 dilakukan dengan cara: 1 ) memberikan pelatihan tentang manajemen pembelajaran daring bagi guru MI Tarbiyatul Islamiyah Bojonegoro, 2) melakukan pendampingan pasca pelatihan agar dapat memantau perubahan yang terjadi setelah pelatihan. Manfaat dari pengabdian masyarakat tersebut adalah untuk menambah pengetahuan guru tentang manajemen pembelajaran daring di tengah pandemi covid 19 bagi guru MI Tarbiyatul Islamiyah Bojonegoro

\section{METODE}

Pelatihan dan pendampingan manajemen pembelajaran daring bagi guru di tengah pandemi covid 19 di MI Tarbiyatul Islamiyah Bojonegoroini diikuti oleh 12 peserta dari guru MI Tarbiyatul Islamiyah Bumirejo Bojonegoro. Tempat pelatihan di MI Tarbiyatul Islamiyah Bumirejo Bojonegoro. Pelaksanaan pelatihan diawali dengan penjelasan materi menggunakan power point. Kemudian praktek mengelola pembelajaran daring mulai dari perencanaan, pelaksanaan dan evaluasi. Selanjutnya para peserta akan praktek membuat merencanakan, melaksanakan dan membuat evaluasi pemebelajaran daring untuk siswa.

Metode pelaksanaan dalam program pengabdian kepada masyarakat melalui Pelatihan dan pendampingan manajemen pembelajaran daring bagi guru di tengah pandemi covid 19 di MI Tarbiyatul Islamiyah Bojonegoro ini melalui tiga kegiatan yaitu :

\section{Pra Kegiatan}

Rapat strategi pelaksanaan akan dipimpin oleh ketua pelaksana untuk membahas mengenai strategi dan perencanaan program pengabdian pada masyarakat yang akan dilaksanakan. Kedua, survei dilakukan paling lambat satu hari sebelum dilaksanakan kegiatan untuk mengatur tata letak perlengkapan dan bentuk kegiatan. Ketiga, tahap ini merupakan tahap dalam mempersiapkan sarana dan prasarana yang mendukung kegiatan ini. Persiapannya adalah menyiapkan tempat dan lokasi yang akan digunakan untuk kegiatan pelatihan dan 
pendampingan. Sarana yang lainnya akan dipersiapkan secara bertahap dengan mempertimbangkan tingkat kebutuhan, yakni: pembuatan spanduk kegiatan, peminjaman proyektor.

\section{Pelaksanaan Kegiatan}

Tahap pelaksanaan kegiatan adalah tahap utama dari program pengabdian kepada masyarakat. Peserta dalam kegiatan pelatihan dan pendampingan manajemen pembelajaran bagi guru di tengah pandemi covid 19 di $\mathrm{MI}$ Tarbiyatul Islamiyah Bojonegoro. Teknis pelaksanaan kegiatan pelatihan ini adalah pemateri memberikan penjelasan terlebih dahulu tentang konsep manajemen pembelajaran daring mulai dari tahap perencanaan, pelaksanaan dan evaluasi. Selanjutnya peserta mulai mempraktekkan membuat perencanaan, pelaksanaan dan evaluasi pembelajaran daring. Monitoring dan evaluasi kegiatan dilakukan dengan mnyebarkan angket pada peserta untuk memantau keberhasilan program pengabdian masyarakat.

\section{HASIL DAN PEMBAHASAN}

Manajemen adalah suatu ketrampilan dan kemampuan khusus yang dimiliki oleh seseorang untuk mencapai tujuan yang efektif dan efesien (Nafiah, 2017). Sedangkan manajemen pembelajaran merupakan kemampuan dalam mengelola secara operasional dan efesien terhadap komponenkomponen yang berkitan dengan pembelajaran, sehingga menghasilkan nilai tambah terhadap komponen tersebut menurut norma/standar yang berlaku(Yamin and Maisah, 2010). Pembelajaran daring diartikan sebagai pembelajaran yang dilaksanakan secara online. Mata pelajaran yang disampaiakan dapat berupa rekaman video atau slideshow, dengan tugas-tugas mingguan yang harus dikerjakan dengan batas waktu pengerjaan yang telah ditentukan dan beragam sistem penilaian (Nugraha, Sudiatmi and Suswandari, 2020). Manajemen pembelajaran daring merupakan suatu kegiatan pengelolaan pembelajaran dari mulai dari perencanaan, pelaksanaan dan evaluasi pembelajaran yang dilakukan guru.

Kegiatan pelatihan dan pendampingan pembelajaran dari dilakukan dengan sukses. Peserta pelatihan antusias dalam mengikuti kegiatan pelatihan. Untuk tidak lanjut dalam kegiatan pelatihan dilakukan pendampingan secara daring dengan menggunakan aplikasi google classroom. Sebelum pelatihan guru masih banyak yang belum mengetahui cara membuat google classroom dan membuat penugasan, membuat kuis dengan aplikasi google classroom. Setelah kegiatan guru telah memahami dan dapat membuat soal secra online/daring. Berikut ini merupakan foto kegiatan pengabdian masyarakat di $\mathrm{Ml}$ tarbiyatul Islamiyah Bumirejo, Kepohbaru Bojonegoro:

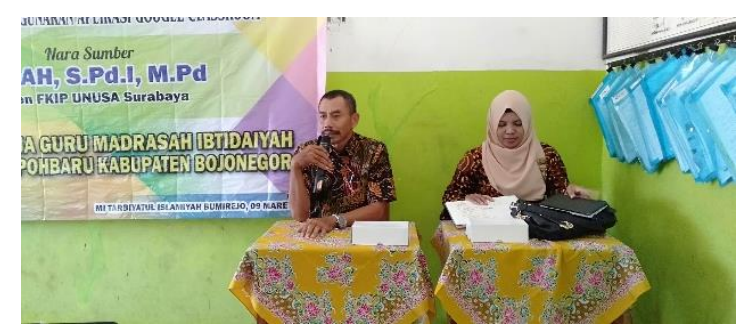

Gambar 1. Kegiatan Pembukaan Pelatihan dan pendampingan Manajemen pembelajaran daring di MI Tarbiyatul Islamiyah Bumirejo Bojonegoro

Kegiatan pelatihan dibuka oleh ketua KKG dari Kepohbaru Bojonegoro sebagai dan dibuka oleh kepala sekolah $\mathrm{Ml}$ tarbiyatul Islamiyah Bumirejo Bojonegoro. Ketua KKG merespon dengan positif kegiatan pelatihan dan pendampingan manajemen pembelajaran daring yang dilakukan oleh tim dosen FKIP. Pelatihan pembelajaran daring dilakukan pada guru agar guru memiliki pengetahuan dan pemahaman platform yang bisa digunakan dalam memanajemen pembelajaran daring. Pembelajaran daring memiliki kelebihan tidak memerlukan ruang kelas, siswa dapat melaksanakan pemeblajaran di rumah, guru tidak perlu tatap muka di kelas tapi bisa dilakukan di tepat atau lingkungan guru masing-masing Karen hanya menggunakan Handphon/ computer/leptop, pembelajaran bisa dilakukan kapanpun (Santika, 2020).Pembelajaran daring dapat berlangsung efektif dan efesien jika fasilitas guru dan siswa terpenuhi.

Pembelajaran daring pada kegiatan pelatihan dan pendampingan di MI Tarbiyatul Islamiyah Bojonegoro dilakukan dengan menggunakan salah satu aplikasi google classroom karena aplikasi tersebut mudah untuk digunakan bagi guru. Hal tersebut sesuai dengan hasil penelitian yang menyebutkan Classroom ataupun Zoom-Meet telah memenuhi klasifikasi kualitas, teknologi dan dapat menjadi sarana komunikasi yang menghubungkan (related) dalam pembelajaran daring(Swasti, 2020).Berdasarkan Hasil Pelatihan dan pendampingan manajemen pembelajaran berbasis daring dengan menggunakan aplikasi google classroom di peroleh data ketrampilan guru dalam menggunakan google classroom 
sebelum dan setelah pelatihan dan pendampingan, adalah sebagai berikut:

Hasil Kemampuan Memanajemen Pembelajaran Berbasis Daring

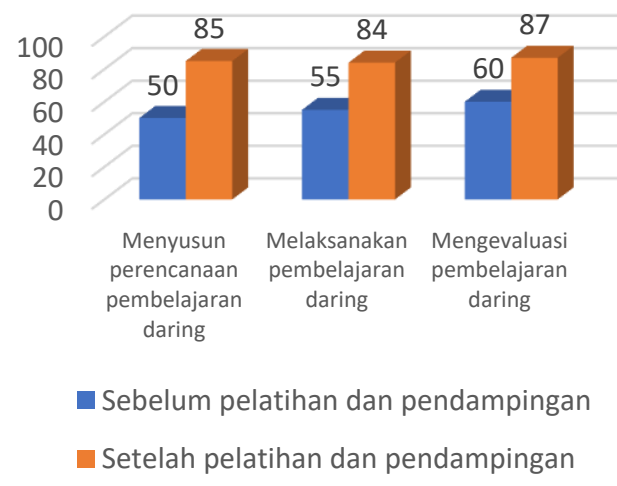

Gambar 2. Hasil Kemampuan Memanajemen Pembelajaran Sebelum dan Setelah Pelatihan dan Pendampingan

Berdasarkan Gambar 1 diperoleh hasil kemampuan dalam manajemen pembelajaran daring MI kecamatan Kepohbaru Bojonegoro dalam menyusun perencanaan pembelajaran sebelum pelatihan dan pendampingan mendapatkan nilai rata-rata 50 dan setelah mendapatkan pelatihan dan pendampingan mendapatkan nilai rata-rata 85 . Kemampuan guru dalam melaksanakan/menggunakan pembelajaran daring sebelum pelatihan dan pendampingan mendapatkan nilai rata-rata 55 dan setelah mendapatkan pelatihan dan pendampingan mendapatkan nilai rata-rata 84 . Sedangkan kemampuan guru dalam melakukan evaluasi pembelajaran daring seperti membuat kuis secara online sebelum diberikan pelatihan dan pendampingan sebesar 60 dan setelah diberikan pelatihan dan pendampingan naik menjadi 87. Peserta pelatihan sangat antusas dalam megikuti pelatihan, berikut ini merupakan foto kegiatan pelatihan:

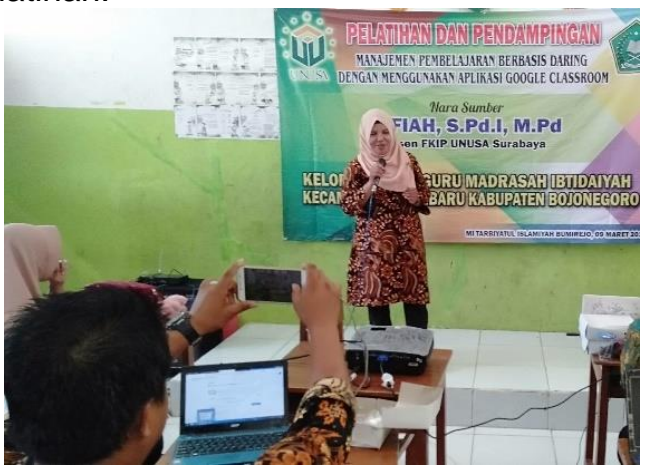

Gambar 3. Antusias guru dalam memperhatikan kegiatan pelatihan manajemen pebelajaran daring bagi guru MI
Penggunaan teknologi pada pembelajaran daring dimasa pandemic covid 19 sangat diperlukan untuk membantu guru dalam melaksanakan kegiatan pembelajaran. Selain google scholar teknologi yang bisa dimanfaatkan untuk pembelajaran daring adalah blockchain. Pemanfaatan teknologi blockchain dalam manajemen bidang pendidikan merupakan langkah baik untuk dilakukan oleh Indonesia dikarenakan akan banyak mendapatkan keuntungan dan minat yang banyak sehingga dapat membentuk soft skills dan hard skills(Agustin et al., 2020). Kegiatan pelatihan dan pendampingan manajemen pembelajaran daring bagi guru di tengah pandemi covid 19 di Ml Tarbiyatul Islamiyah Bojonegoro merupakan kegiatan yang dapat membantu guru dalam merencanakan, melaksanakan dan melakukan evaluasi pembelajaran secara daring pada siswanya nanti.

\section{SIMPULAN DAN SARAN}

Kegiatan pelatihan dan pendampingan manajemen pembelajaran berbasis daring Pelatihan dan pendampingan manajemen pembelajaran daring bagi guru di tengah pandemi covid 19 di MI Tarbiyatul Islamiyah Bojonegoro berjalan dengan sukses karena dukungan dari berbagai pihak yang terlibat dengan pengabdian mansyaraat. Guru sangat antusias dalam kegiatan pelatihan dan pendampingan secara daring, guru juga sudah memahami caramerencanakan, melaksanakan dan mengevaluasi siswa secara daring.

Rencana tindak lanjut pelaksanaan pengabdian masyarakat sebagai saran adalah mengadakan pelatihan dan pendampingan dalam melaksanakan pembelajaran daring dengan menggunakan aplikasi digital bagi guru sekolah dasar.

\section{UCAPAN TERIMAKASIH}

Penulis ucapkan terima kasih kepada LPPM UNUSA yang telah memberikan batuan dana untuk pelaksanaan pengabdian masyarakat, pada MI Tarbiyatul Islamiyah Bumirejo Bojonegoro yang telah bersedia bekerjasama dalam kegiatan pengabdian masyarakat.

\section{DAFTAR RUJUKAN}

Agustin, F. et al. (2020) 'Manajemen Pembelajaran Daring Menggunakan Education Smart Courses', Technomedia Journal, 5(1), pp. 40-53. doi: $10.33050 /$ tmj.v5i1.1315.

Alharbi, S. and Drew, S. (2014) 'Using the technology acceptance model in 
understanding academics behavioural intention to use learning management systems', International Journal of Advanced Computer Science and Applications, 5(1), pp. 143-155.

Nafiah, N. (2017) 'Manajemen Pembelajaran Tematik Integratif Sesuai Kurikulum 2013 Pada Kelas 4 Sd Khadijah Surabaya', Education and Human Development Journal, 2(1), p. 60=71. doi: 10.33086/ehdj.v2i1.385.

Nafiah, N. and Hartatik, S. (2020) 'Penerapan Manajemen Pembelajaran Berbasis Daring Dengan Menggunakan Aplikasi Google Classroom Untuk Meningkatkan Kemampuan Mahasiswa Dalam Membuat Perangkat Pembelajaran', 5(April), pp. 9-23. doi: 10.33086/ehdj.V5i1.1486.

Nugraha, S. A., Sudiatmi, T. and Suswandari, M. (2020) 'Studi Pengaruh Daring Learning Terhadap Hasil Belajar Matematika Kelas IV', Jurnal Inovasi Penelitian, 1(3), pp. 265-276.

Santika, I. W. E. (2020) 'Pendidikan Karakter pada Pembelajaran Daring', Indonesian Values and Character Education Journal, 3(1), pp. 8-19.

Swasti, I. K. (2020) 'Implementasi Manajemen Pembelajaran Daring Dengan Platform WA, CR, M-Z dan Kepuasan Mahasiswa', JAMP: Jurnal Adminitrasi dan Manajemen Pendidikan, 3(4), pp. 342-351.

Yamin, M. and Maisah (2010) Standarisasi Kinerja Guru, Jakarta: Gaung Persada. 